\title{
EQUiLIBRIUM
}

Quarterly Journal of Economics and Economic Policy

2016 VOLUME 11 ISSUE 4, December

p-ISSN 1689-765X, e-ISSN 2353-3293

www.economic-policy.pl

Brózda, D. (2016). Transmission Mechanism of the Federal Reserve System's Monetary Policy in the Conditions of Zero Bound on Nominal Interest rates. Equilibrium. Quarterly Journal of Economics and Economic Policy, 11(4), 751-767. DOI: http://dx.doi.org/10.12775/EQUIL.2016.034

Dominika Brózda*

University of Lodz, Poland

\section{Transmission Mechanism of the Federal Reserve System's Monetary Policy in the Conditions of Zero Bound on Nominal Interest Rates}

JEL Classification: E52; E58

Keywords: monetary policy; interest rate; transmission mechanism of monetary policy; zero lower bounds

\begin{abstract}
The experience of Japan from the 90s of the twentieth century and the recent global financial crisis has shown that the zero lower bound problem has ceased to be a theoretical curiosity and became the subject of intense scientific discussion. This issue is closely linked with John Maynard Keynes's liquidity trap. The phenomenon of the zero lower bound is very controversial. Not all economists agree that it may restrict the effectiveness of the central bank's actions. The aim of the article is to present the views of economists on this transmission mechanism of monetary policy under the zero lower bound. The paper also attempts to evaluate the effectiveness of the Federal Reserve System's monetary policy at zero nominal interest rates.
\end{abstract}

(C) Copyright Institute of Economic Research

Date of submission: April 2, 2015; date of acceptance: May 14, 2016

* Contact: dominika.brozda@gmail.com, University of Lodz, Faculty of Economics and Sociology, ul. Rewolucji 1905 r 37/39, 91-214 Łódź, Poland 


\section{Introduction}

In the stable macroeconomic conditions monetary policy of the Federal Reserve System (Fed), like monetary policy of any other central banks, affects the term structure of nominal interest rates as well as other asset prices, and thus influences aggregate demand through these effects. Generally, we may conclude that by causing changes in the market interest rates, financial market conditions and the dollar exchange rate, monetary policy actions have significant effects on output, employment and prices (Akhtar, 1997, p. 10). This complex process is known as the monetary transmission mechanism.

The global financial crisis, which began in the U.S. subprime mortgage market in 2007, has changed the monetary transmission mechanism of the Federal Reserve System. The emergence of the close to zero nominal interest rates problem has caused the U.S. central bank to be incapable to effectively influence the economy through standard monetary policy instruments (i.e. interest rate policy). It is worth stressing the fact that the zero lower bound phenomenon is very controversial. Not all economists agree that it may restrict the effectiveness of the central bank's actions (Błaszczyk, 2010, p. 26).

The aim of the article is to present the views of economists on transmission mechanism of monetary policy under the zero lower bound. The paper also attempts to evaluate the effectiveness of the Federal Reserve System's monetary policy in the years 2009-2014. The empirical analysis covers the period of historically extremely low level of the target federal funds rate.

\section{Research Methodology}

The paper reviews the literature of the subject on the monetary transmission mechanism in the conditions of zero lower bound on nominal interest rates (ZLB). Within this study, statistical analysis and methods of deduction were used. The empirical analysis was carried out on the basis of U.S. economic statistics for the years 2008-2014 which were taken from the FRED Database. 


\section{The Zero Lower Bound Problem on Nominal Interest Rates}

The zero lower bound on nominal interest rates implies that they could not be reduced below a certain level. Nominal interest rates should not be expected to fall below zero, since securities would then be characterized by a negative rate of return and therefore possession of such assets would not bring any benefits (Jurek, 2004, pp. 25-26).

Within the literature, it is emphasized that the lower bound on nominal interest rate could be only theoretically different from zero. According to Goodfriend (2000, p. 41), the interest rate could be negative if the storing of money led to some extraordinary costs or mental discomfort. Yates (2002, pp. 12-13) argues that this bound could be greater than zero to the extent that there would be some significant benefits from holding cash that would not diminish as real balances rise.

The experience of Japan from the 90s of the twentieth century, and the recent global financial crisis, have shown that the problem of zero bound has ceased to be a theoretical curiosity and became the subject of intense scientific discussion. This issue is closely linked with John Maynard Keynes's liquidity trap (Żywiecka, 2013, p. 71).

When the nominal interest rate is close to zero, the real short-term interest rate (reflecting the prevailing deflationary expectations) may be higher than the interest rate required to ensure stable prices and make full use of production factors. Excessively high real interest rates put pressure on reducing costs and falling prices. Thereby a further increase in real interest rates leads to the so-called 'effect of vicious circle' (Bernanke et al., 2004, p. 1).

Studying Japan's financial crisis of the 1990s, economists have identified several solutions that may facilitate recovery from a recession during the liquidity trap. According to Wojtyna (2001, pp. 15-16), the most important of these concepts are the following:

- the depreciation of the exchange rate which might be carried out on the portfolio balance channel ${ }^{1}$,

- the implementation a set of non-standard monetary policy transmission channels, among others, through direct central bank purchase of securities,

\footnotetext{
${ }^{1}$ Under the portfolio balance channel, the depreciation of the exchange rate might be caused by permanent changes in expectations on the structure of domestic and foreign money supply.
} 
- the setting higher inflation target for several years in order to cause i.e. the Summers's effect,

- the introduction of the tax on cash and bank reserves (the so-called 'carry tax on money'),

- the implementation of the eclectic method of expansionary monetary policy, the so-called 'a foolproof way' - which involves the announcement of the price-level target path (corresponding to small positive longrun inflation target), the devaluation of the national exchange rate and introduction of a temporary exchange-rate peg.

Within this context, the aforementioned Summers's effect is worth noting. This phenomenon shows that inflation target may be a 'security buffer' in the case of reducing nominal interest rates to zero. This buffer facilitates the use of negative real interest rates to stimulate economic growth (Błaszczyk, 2010, pp. 26). This approach is based on the assumption that 'inflation greases the wheels of monetary policy' (Fischer, 1996, p. 19).

It should be also emphasized that under the ZLB on nominal interest rates monetary authorities seek alternative ways in relation to the interest rate channel, which would be effective in promoting long run economy growth. Bernanke et al. (2004) consider that the positive impact of monetary impulses on economic activity at zero interest rates might be achieved in three complementary ways, i.e. by (Bernanke et al., 2004, pp. 3):

- using communications policies i.e. forward guidance on policy rates,

- increasing the size of the central bank's balance sheet,

- changing the composition of the central bank's balance sheet.

The specificity of forward guidance policy is based on publication future path of the official interest rate. Central bank promises to keep the nominal interest rate low for an extended period, and thereby shapes public expectations about the future course of interest rates in order to provide anchoring medium- and long-term interest rates expectations at the low level. The effectiveness of this monetary transmission channel depends to a large extent on (Walsh, 2014, pp. 2-3):

- the central bank's credibility,

- the proper understanding of the Fed's monetary policy intentions by market participants.

It should be stressed, however, that making an unambiguous assessment of the forward guidance effectiveness is impossible due to a few empirical studies regarding this instrument. On the one hand, the results of analyses indicate its positive effect of forward guidance on anchoring interest rates expectations, on the other hand, the estimated scale of its impact varies widely (Filardo \& Hofmann, 2014, p. 49). Moreover, those bodies of research imply that the credibility of forward guidance policy decreases with 
the lengthening time horizon. It is probably related to the growing uncertainty about the future economic outlook that reduces the accuracy of forecasts underlying the formation of forward guidance on policy rates (NBP, 2013, p. 43).

In the absence of the ability to further reduce short-term interest rates, another method of impact on financial system liquidity might be quantitative easing policy $(\mathrm{QE})$. Under this policy, the monetary authorities acquire financial assets both the public sector and private sector. These activities are designed to stimulate economy by reducing the long-term interest rates (Żywiecka, 2013, p. 76).

Purchasing securities with newly issued funds contributes to rise supply of liquid reserves in the banking system and expansion of the money supply. On top of that, purchase of assets should result in increased their prices and decreased yields. Consequently, the lower interest rates securities, which reducing the cost of credit for businesses and households, may lead to an increase in aggregate demand. Cheaper and wider access to investment loans might help businesses to keep output at current levels by improving employment perspectives. The higher asset prices may also enhance profits of assets owners. The above described dependencies are illustrated in Figure 1.

Figure 1. Monetary policy transmission mechanism through the QE policy

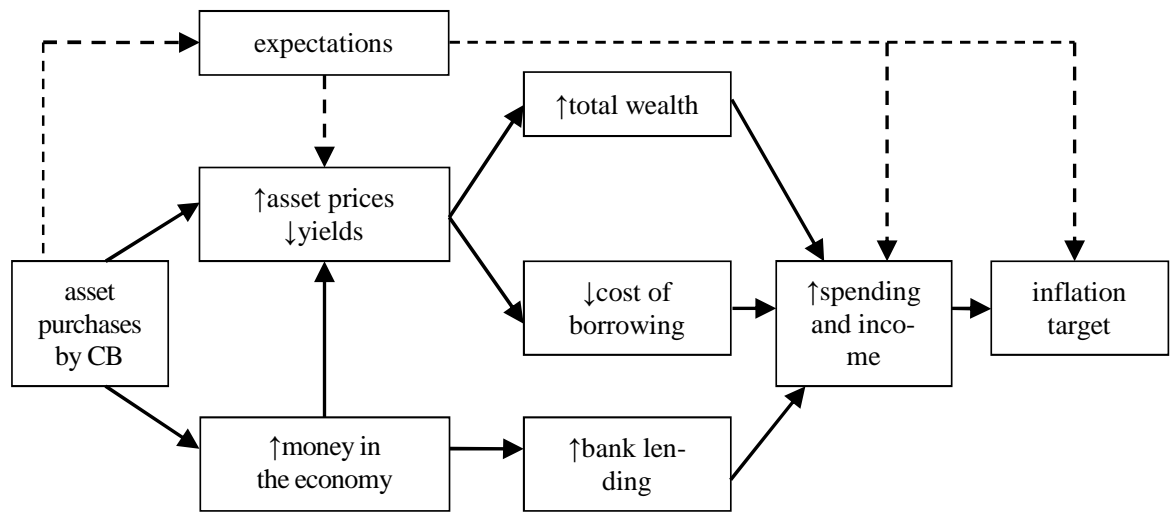

Source: Bank of England (2009, pp. 17). 
It is worth noting that the effectiveness of the QE policy depends on financial institutions' decisions concerning the destination of acquired reserves. This policy will be effective if obtained liquidity (from asset sales to the central bank) is intended for the purchase of other securities. On the other hand, this kind of policy will be ineffective if additional funds are retained in the form of liquidity buffer (Bank of England, 2009, p. 16).

Figure 1 shows one of the possible ways on how unconventional monetary policy might affect the real economy in the conditions of the ZLB. It should be emphasized that quantitative easing policy can influence the economic processes via multiple channels, which are differently classified in the literature. For instance Joyce et al. (2010, pp. 7-8) identify the following possible ways of transmission quantitative easing policy impulses:

- Macro-policy news channel - that is associated with the above presented instruments such as forward guidance policy. Within this channel, central bank's announcements of assets purchase provide economic agents with additional information about the underlying state of the economy.

- Portfolio rebalancing channel - under that form of transmission, it should be emphasized that demand increase for bonds should lead to raising their prices and decreasing yields. In particular, central bank's assets purchase reduces the amount of asset held by the private sector, and replaces it with risk-free reserves. Furthermore, investors who have sold their assets will bid up the price of other assets (provided that assets are imperfect substitutes).

- Market functioning effect - based on the expectation that the presence of the central bank in the market as a significant buyer of assets may reduce liquidity premium. Assets purchases by monetary authorities may make it easier for market participations to sell assets when required.

Against Joyce et al. (2010), Bernanke et al. (2004, pp. 16-18) distinguish three other possible transmission mechanism channels of quantitative easing to the real economy:

- Portfolio balance channel ${ }^{2}$ - the functioning of this channel is based on the assumption that money and other financial assets are imperfect substitutes. According to this view, the increase in the money supply may induce the private sector to rebalance portfolios through the exchange of money for less liquid assets. It may contribute to increase the prices of non-money asset, decreased the yields of these assets and in turn, stimulate the economy.

\footnotetext{
${ }^{2}$ Bernanke et al. (2004) did not specify the name of this transmission channel. However, according to the author of this article, this channel can be identified with portfolio balance channel.
} 
- Fiscal channel - Bernanke et al. (2004, pp. 17) emphasize that sufficiently large monetary injections may materially relieve the government's budget constraint. It may permit to reduce taxes or increase government spending.

- Signaling channel - a mechanism under which QE may complement the expectations management approach. It provides a visible signal to the public about the central bank's intended future policies.

This notwithstanding, it is worth highlighting that the question about the medium and long term implications of unconventional monetary policy remains open. Rzońca (2014, pp. 178-179) draws attention to some possible, negative consequences of the monetary policy conducted in the conditions of ZLB. According to him, it may cause among others:

- delays in economic restructuring,

- increased uncertainty in the economy,

- enhancement of the economy sensitivity to negative shocks.

What is more, the QE policy and very low interest rates might also facilitate the rapid increase in budgets deficits and public debts. Low government borrowing costs reduce tendency to structural reforms and the economic growth. Therefore, Rzońca (2014, pp. 383-384) shows that unconventional monetary policy leads to chronic deficits and high chronic deficit forces to extend the period of non-standard measures.

\section{Non-standard Federal Reserve System's Monetary Transmission Mechanism}

Fed has engaged in an accommodative monetary policy in response to increasing turbulence in the U.S. financial system, low economic growth and deflationary tendencies. On December 16th, 2008, Federal Open Market Committee (FOMC) decided to reduce target federal funds rate by 75 basis points to $0.25 \%$ - the lowest level in Fed's history. Since then, FOMC has kept the target range for the federal funds rate at 0 to 25 basis points. Thus it may be concluded that Fed employed the low interest rates policy at the end of 2008 (NBP, 2014, p. 92).

Disturbances in monetary transmission mechanism in United States during the financial crisis, mainly the interest rate transmission, resulted in the necessity of the introduction of other methods of monetary policy implementation. In conjunction with the impossibility to pursue a more expansionary interest rate policy, Fed attempted to mitigate the situation on the financial market and to stimulate economic growth, among others, by in- 
creasing the amount of liquid reserves in the financial system (Tymoczko, 2011, p. 219).

Since the beginning of 2009, the U.S. central bank has initiated a series of asset purchases (among others, mortgage-backed securities and Treasury bonds) under QE of monetary policy comprising four programmes. They adopted the single name as Large-Scale Asset Purchase (LSAP) mainly on account of the applied procedures. The mechanism of all those programmes consisted in the exchange of longer-maturity assets for debt securities with shorter-term or zero maturity (i.e. central bank reserves). By changing the relative supply of assets in the respective market segments and decreasing the risk of balance sheet loss, the purchase of Treasury securities was aimed at reducing the interest rate risk in the U.S. financial market (NBP, 2013, p. 16).

Figure 2 shows that the impact on financial markets by using unconventional monetary policy with bypassing the traditional interest rate channel, i.e. 'decoupling principle' is a characteristic feature of the Fed's monetary transmission mechanism since December 2008 (Żywiecka, 2013, p. 74). Both the communication policy and the balance sheet policy play a special role in this process. Via these tools, the Fed has attempted to improve financial market conditions and revive the economic situation in the United States.

An extremely expansionary monetary policy, which is implemented under ZLB, influences the real economy via several channels (Figure 2). In literature these channels are listed as (McCarthy, 2013, p. 20):

- non-traditional interest rate channel,

- bank lending channel,

- private nonfinancial balance sheets channel,

- wealth channel,

- exchange rate channel,

- portfolio balance channel.

It is worth stressing that the smooth operation of mentioned above transmission channels is conditioned on shaping expectations of the QE policy actions among market participants and anchoring expectations both of low nominal interest rates and low real long-term interest rates (Figure 2). 
Figure 2. Federal Reserve System's monetary policy transmission mechanism from December 2008

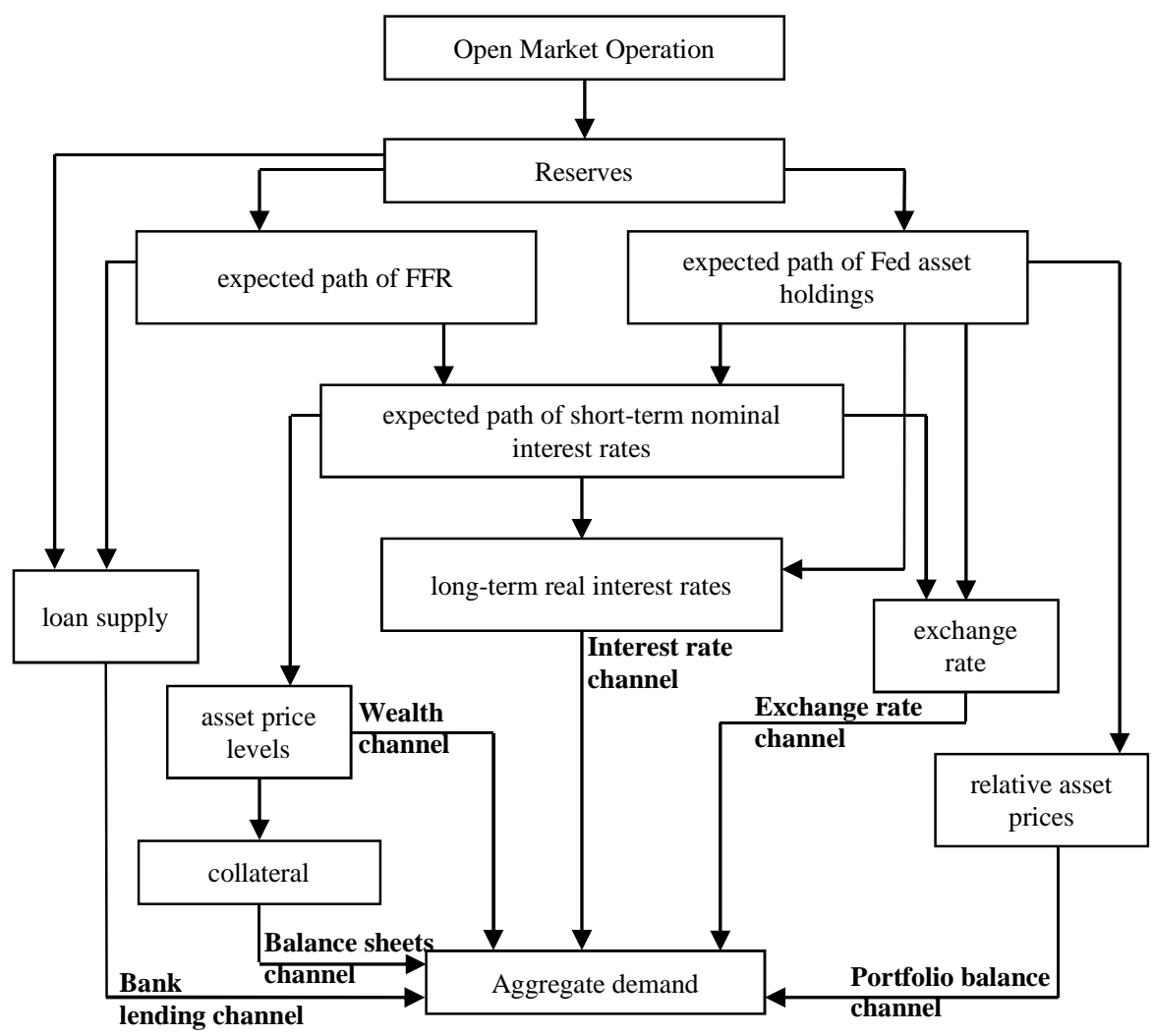

Source: McCarthy (2013, s. 20).

\section{Assessment of the Fed's Monetary Policy in the Period 2008-2014}

Analyzing the effectiveness of the Fed's monetary policy in the years 2009-2014, attention must be drawn to modification of the U.S. central bank's mandate which was implemented in January 2012. The dual mandate of the Federal Reserve System was extended by quantitative approach to monetary policy goal. In the Press Release dated on January 25, 2012 FOMC highlighted that inflation at the rate of 2 percent, as measured by the annual change in the price index for personal consumption expenditures 
(PCE), is consistent over the longer run with the Federal Reserve's statutory mandate, which commits the Fed to promote effectively the goals of:

- maximum employment,

- stable prices,

- moderate long-term interest rates.

In addition, the Committee emphasized that communicating this longerrun goal for inflation to the public might help to keep inflation expectations firmly anchored, thereby fostering price stability and moderate long-term interest rates. It could also enhance the FOMC's ability to promote maximum employment in the face of significant economic disturbances (Board of Governors, 2012).

The provisions, contained in the above mentioned press release, were repeated in the official statement on longer-run goals and monetary policy strategy within 'the Monetary Policy Report to the Congress' dated on July 17, 2013. In this statement, the FOMC members stressed that stable prices and maximum employment are still generally complementary monetary policy objectives. Moreover, as of 2013 in setting monetary policy, the FOMC would seek to mitigate deviations of inflation from its longer-run goal and deviations of employment from the Committee's assessments of its maximum level (Board of Governors, 2013).

Data in Figure 3 shows that the adoption of a numerical target for inflation contributed to anchor long-run inflation expectations close to the quantitative definition of price stability both in the medium- and long-term. Between 2012 and 2014 inflation expectations in the next 5 and 10 years (measured by breakeven inflation rates $^{3}$ ) stabilized at the average level annualized $2 \%$. However, during that period, the average annual rate of inflation as measured by PCE index was about annualized $1.5 \%$, which was below the adopted target amount.

Anchoring of stable prices expectations in the U.S. economy is also confirmed by another measure of long-term inflation expectations - the fiveyear, five-year forward inflation expectation rate ${ }^{4}$. The value of this indicator shows that market participants expected inflation rate in excess of $2 \%$ in the second half of the nearest decade.

\footnotetext{
${ }^{3}$ The breakeven inflation rate - represents the spread between nominal constant maturity Treasury securities and inflation-indexed Treasury securities.

${ }^{4}$ The five-year, five-year forward inflation expectation rate - represents a measure of expected inflation over the five-year period that begins five years from today.
} 
Figure 3. Inflation rates and inflation expectations in United States in the period 2008-2014 (in \%)

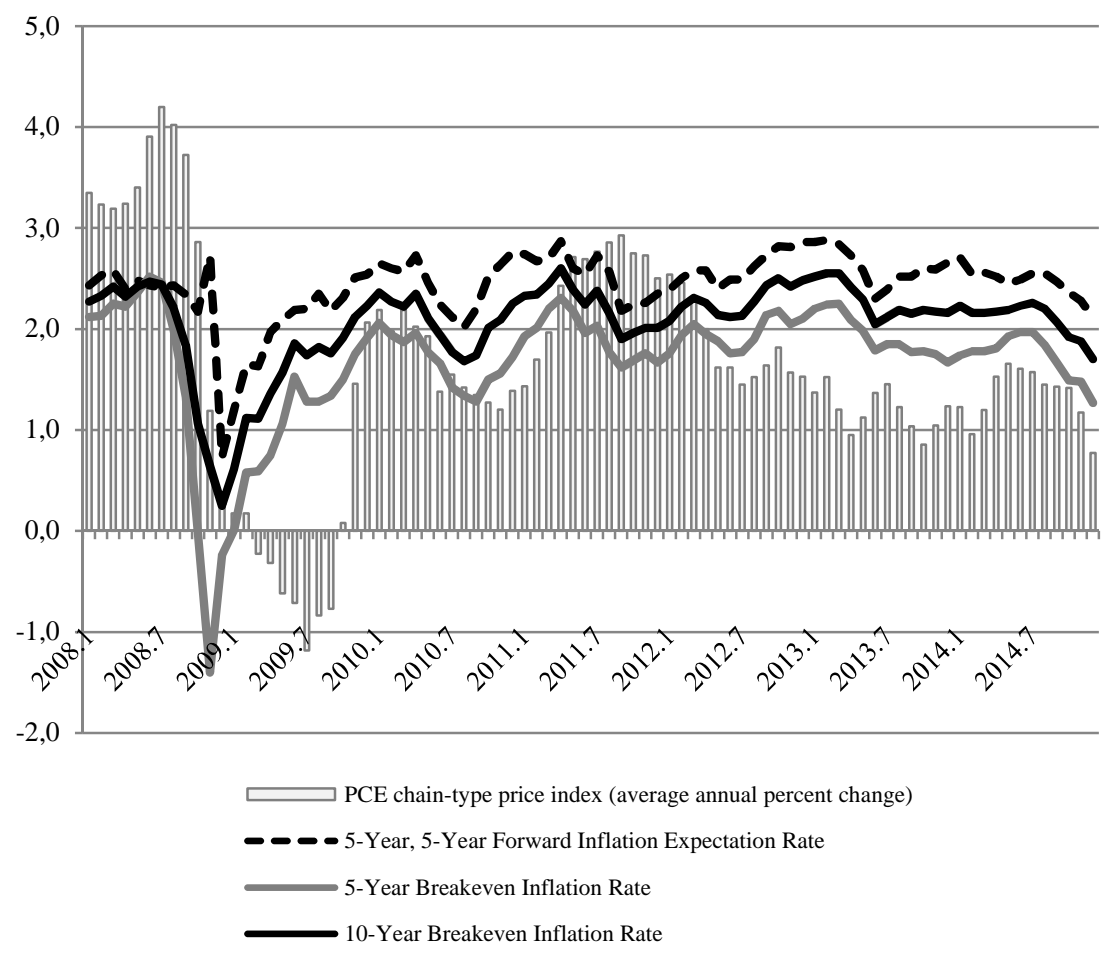

Source: own calculations based on the Federal Reserve Bank of St. Louis, Federal Reserve Economic Data (FRED). Retrieved form http://research.stlouisfed.org/fred2/ (27.02.2015).

It is worth highlighting that since January 2009 a significant increase in inflation expectations (Figure 3) contributed to reduction of long-term real interest rates (Figure 4). According to the author of this article, attention must therefore be drawn to the occurrence of the Summers's effect in the U.S. central bank's monetary policy.

Firstly, in the period 2009-2014, nominal yields on ten-year U.S. government bonds decreased on average, about 1.13 percentage points (pp). Between 2012 and 2013, there was only a slight increase in the profitability of these securities (remaining still at a historically low level) due to the reduction of investors risk aversion. 
Figure 4. Ten-year yields on U.S. government bonds and key macroeconomic variables in United States in the period 2008-2014

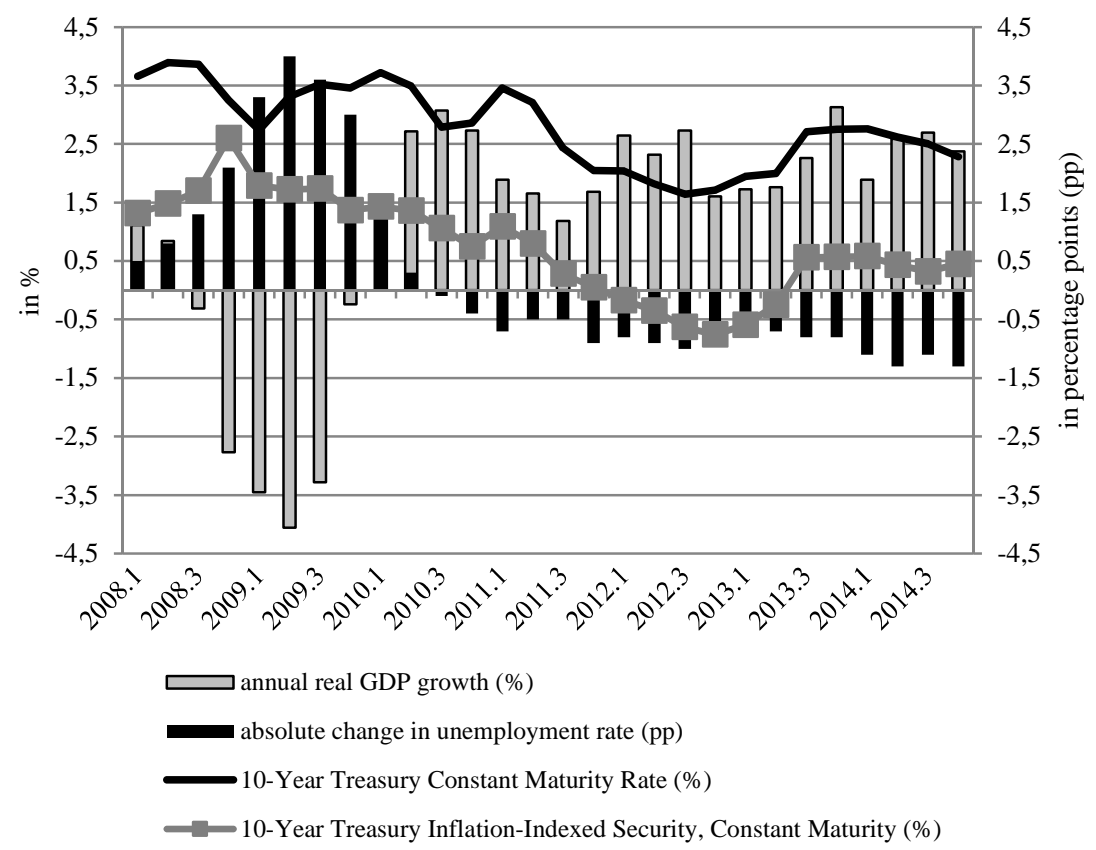

Source: own calculations based on the Federal Reserve Bank of St. Louis, Federal Reserve Economic Data (FRED). Retrieved form http://research.stlouisfed.org/fred2/ (27.02.2015).

Secondly, in the period covered by the analysis, the real ten-year yield on U.S. government bonds also declined by an average of $2 \mathrm{pp}$. This variable was negative from the first quarter of 2012 to the second quarter of 2013. Furthermore, it is useful to draw attention that the period of very low real long-term interest rates coincided with the period of an increase in real GDP growth rate and a decline in the unemployment rate. The growth rate of U.S. real GDP was on the average level of $2.31 \%$ in the years 2012 2014. According to the author of the article, basing on these data it may be argued that Fed's monetary policy at the ZLB contributed to stimulate the U.S. economic growth. 
Figure 5. The level of term, risk and liquidity premium in United States in the period 2008-2014 (in percentage points)

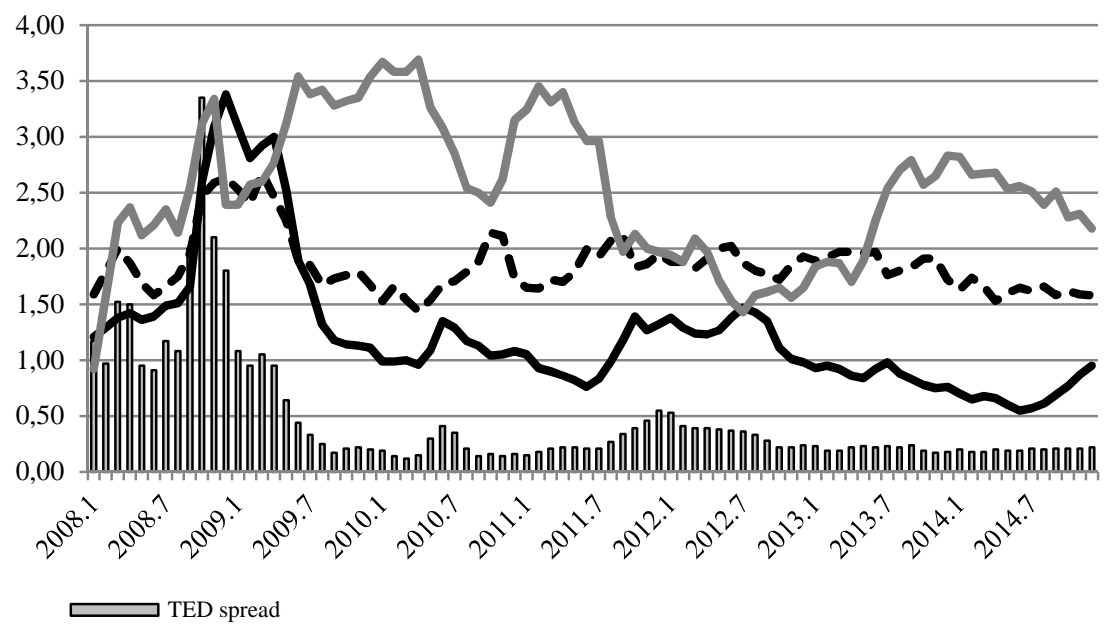

\footnotetext{
- spread between the rate of return on corporate bonds with a rating of Aaa and the 10-year yield on U.S. Treasury securities

spread between the rate of return on corporate bonds with a rating of Baa and Aaa

spread between the 10-year yield and 3-month yield on U.S. Treasury securities
}

Source: own calculations based on the Federal Reserve Bank of St. Louis, Federal Reserve Economic Data (FRED). Retrieved form http://research.stlouisfed.org/fred2/ (27.02.2015).

The effectiveness of the Federal Reserve System's unconventional monetary policy might be also confirmed by data on the above graph. Figure 5 shows that in the long-term perspective monetary policy under the ZLB has contributed to lowering:

1) term premium - which is calculated as the spread between the rate of return on long-term and short-term securities.

2) risk premium - which is measured by:

- the difference between the rate of return on corporate bonds and the risk-free interest rate (for instance the ten-year yield on U.S. Treasury securities),

- the spread between the rate of return on corporate bonds with a rating of Baa and Aaa, 
3) interbank market liquidity premium - which is measured by the TEDspread indicator ${ }^{5}$.

Table 1. The synthesis of research results concerning Fed's monetary policy at the zero lower bound on nominal interest rates

\begin{tabular}{|c|c|c|}
\hline $\begin{array}{l}\text { Authors of } \\
\text { research }\end{array}$ & $\begin{array}{l}\text { Method of } \\
\text { research }\end{array}$ & Main conclusions \\
\hline Wright (2012) & $\begin{array}{l}\text { structural VAR } \\
\text { model }\end{array}$ & $\begin{array}{l}\text { In the period 2008-2011 Fed's unconventional monetary } \\
\text { policy at the ZLB had a slight, but a stimulating impact on the } \\
\text { economy. The effects of monetary impulses were unstable. } \\
\text { Monetary policy affected to a greater extent on government } \\
\text { bond yields than corporate bond yields. }\end{array}$ \\
\hline $\begin{array}{l}\text { Chung et al. } \\
\text { (2011) }\end{array}$ & $\begin{array}{l}\text { the Federal } \\
\text { Reserves's } \\
\text { FRB/US model }\end{array}$ & $\begin{array}{l}\text { The significant support for the real economic activity and the } \\
\text { labor market was provided by the Fed's LSAP programmes. } \\
\text { The undesirable deflationary pressure was compensated and } \\
\text { the negative consequences of the zero lower bound were } \\
\text { significantly reduced. }\end{array}$ \\
\hline $\begin{array}{l}\text { Gagnon et al. } \\
\text { (2011) }\end{array}$ & $\begin{array}{l}\text { event study } \\
\text { analysis }\end{array}$ & $\begin{array}{l}\text { LSAP led to long-lasting reductions in long-term interest } \\
\text { rates on a range of securities, including securities that } \\
\text { were not included in the purchase programmes. QE policy } \\
\text { contributed to the lower risk premiums and term premi- } \\
\text { ums. However, it was not reflected in lower expectations } \\
\text { of future short-term interest rates. }\end{array}$ \\
\hline $\begin{array}{l}\text { Christiano, } \\
\text { Eichenbaum, } \\
\text { Trabandt (2014) }\end{array}$ & DSGE model & Forward guidance policy had large effects on output. \\
\hline $\begin{array}{l}\text { Krishnamurthy, } \\
\text { Vissing- } \\
\text { Jorgensen (2013) }\end{array}$ & $\begin{array}{l}\text { event study } \\
\text { analysis }\end{array}$ & $\begin{array}{l}\text { In the period 2009-2013, the QE policy was characterized } \\
\text { by limited effectiveness, primarily because it had an effect } \\
\text { only on the prices of purchased securities. Not all term } \\
\text { premium of long-term assets were affected, as assumed by } \\
\text { the Fed. On the one hand purchase of long-term Treasury } \\
\text { securities significantly raised the prices of government } \\
\text { bonds, but on the other hand, it had a limited indirect } \\
\text { impact on the profitability of private sector bonds, and } \\
\text { thus it contributed to the small economic benefits. }\end{array}$ \\
\hline
\end{tabular}

Source: own study.

Average between 2009-2014 the risk premium and the liquidity premium were reduced to the greatest extent. In turn, term premium, which compensates investors for bearing risk of interest rate contained in securities with longer maturities, was decreased to a relatively small extent.

During that period, a decline in the value of the TED-spread indicator by about $63 \%$ might reflect the positive impact of Fed's monetary policy on alleviation of financial market tensions. What is more, the reduction of risk

${ }^{5}$ TED-spread indicator - is calculated as the spread between 3-Month LIBOR based on US dollars and 3-Month Treasury Bill. 
premium might confirm the effectiveness of QE policy transmission through the portfolio balance channel, which was described in the first part of the article. Narrowing of the spread between the rates of return on corporate bonds of about $2 \mathrm{pp}$ indicates that the information about the LSAP programmes might have also affected the profitability of assets which were not the direct object of the Fed's purchase. The obtained result is in line with the ones to be obtained by Gagnon et al. (2011) (Table 1).

Table 1 presents a survey of the research on Fed's monetary policy implementation in the face of the last global financial crisis in which effectiveness both of communication policy and balance sheet policy is analyzed. It should be noted that the presented results are ambiguous. The majority of studies confirm the positive impact of Fed's unconventional monetary policy on the real economy by lowering long-term interest rates. However, there is no consensus on whether U.S. monetary policy at the ZLB has an equally stimulating effect on all segments of the financial market.

At this point, it should be stressed the standpoint of the Chair of the Board of Governors of the Federal Reserve System, who called the balance sheet policy as the process of 'learning by doing' (Bernanke, 2012, p. 6). Therefore, it is very hard to unambiguously assess the effectiveness of unconventional monetary policy instruments used under the ZLB.

\section{Conclusions}

In summary, we may conclude that forward guidance policy and quantitative easing policy have contributed to changing the standard transmission mechanism of monetary policy. The monetary transmission process has been based on expectations. What is more, it should be noted the relatively high efficiency of the Fed's anti-crisis monetary policy. Unconventional actions taken by the U.S. central bank, between 2008-2014, have provided additional economic incentives, which have had favourable effect on economic activity.

Purchase of assets under the LSAP programs resulted in a significant decline in the yields on long-term bonds and other securities. It also contributed to the easing of financial market conditions, supporting credit creation and stimulating the U.S. real economy. Not without significance is also the fact that the implementation of non-standard monetary policy instruments have succeeded in anchoring long-term inflation expectations and reducing the term premium and the risk premium. 
This notwithstanding, since the beginning of 2014 Fed has gradually withdrawn from the unconventional programs that were undertaken in response to the global financial crisis. Therefore, the question about consequences of the 'exit strategy' both for the U.S. economy and the global economy remains open.

At this point, it is also worth stressing that preliminary assessment of the Fed's monetary policy transmission effectiveness in the years 2009-2014 requires further research. At the ZLB the inference about the strength and the persistence of the monetary policy impact on output and inflation should be supplemented by a more detailed empirical study, for example by using an econometric model.

\section{References}

Akhtar, M. A. (1997). Understanding Open Market Operations. Public Information Department Federal Reserve Bank of New York.

Bank of England (2009). Inflation Report. May.

Bernanke, B. S. (2012). Monetary Policy Since the Onset of the Crises. Remarks at the Federal Reserve Bank of Kansas City Economic Symposium, Jackson Hole, Wyoming, August 31, 2012.

Bernanke, B. S., Reinhart, V. R., \& Sack, B. P. (2004). Monetary Policy Alternatives at the Zero Bound: An Empirical Assessment. Brookings Papers on Economic Activity, 2. DOI: http://dx.doi.org/10.2139/ssrn.632381.

Błaszczyk, P. (2010). Stabilność cen - sposoby definicji oraz wyzwania dla polityki pieniężnej. Materiaty i studia NBP, 249.

Board of Governors of the Federal Reserve System. Press Release, January 25, 2012, Retrieved form http://www.federalreserve.gov/newsevents/press/monetary/201 20125c.htm. (20.01.2014).

Board of Governors of the Federal Reserve System, Statement on Longer-Run Goals and Monetary Policy Strategy, In Monetary Policy Report, Washington, D.C., July 17, 2013.

Christiano, L. J., Eichenbaum, M., \& Trabandt, M. (2014). Understanding the Great Recession. NBER Working Paper, 20040. DOI: http://dx.doi.org/10.2139 /ssrn.2474797.

Chung H., Laforte J. P., Reifschneider D., \& Williams J. C. (2011). Estimating the Macroeconomic Effects of the Fed's Asset Purchases. Federal Reserve Bank of San Francisco, Economic Letter, 3.

Filardo, A., \& Hofmann, B. (2014). Forward Guidance at the Zero Lower Bound. BIS Quarterly Review, 1.

Fischer, S. (1996). Why Are Central Banks Pursuing Long-Run Price Stability? In Achieving Price Stability. Federal Reserve Bank of Kansas City. 
Gagnon, J., Raskin, M., Remache, J., \& Sack, B. (2011). The Financial Market Effects of the Federal Reserve's Large-scale Asset Purchases. International Journal of Central Banking, 7(1).

Goodfriend, M. (2000). Overcoming the Zero Bound on Interest Rates Policy. Federal Reserve Bank of Richmond Working Papers, 3. DOI: http://dx.doi.org/ 10.2139/ssrn.2126763.

Joyce, M., Lasaosa, A., Stevens, I., \& Tong, M. (2010). The Financial Market Impact of Quantitative Easing. Bank of England Working Paper, 393/2010. DOI: http://dx.doi.org/10.2139/ssrn.1638986.

Jurek, M. (2004). Kontrowersje wokół skuteczności polityki pieniężnej Banku Japonii w latach 1990-2004. Bank $i$ Kredyt, 35(7).

Krishnamurthy, A., \& Vissing-Jorgensen, A. (2013). The Ins and Outs of LSAPs. The Federal Reserve Bank of Kansas City.

McCarthy, J. (2013). The Monetary Transmission Mechanism. Speech delivered at The Federal Reserve in the 21st Century: A Symposium for College Professors, Federal Reserve Bank of New York. Retrieved form http://www.newyorkfed. org/education/pdf/2013/mccarthy.pdf.

NBP (2013). Raport o inflacji, listopad.

NBP (2014). Koniunktura międzynarodowa, 09/14.

Rzońca, A. (2014). Kryzys Banków Centralnych - skutki stopy procentowej bliskiej zera. Warszawa: C.H. Beck.

Tymoczko, D. (2011). Operacje banków centralnych w okresach kryzysowych. In A. Sławiński (Ed.). Polityka pieniężna. Warszawa: C.H. Beck.

Walsh, C. W. (2014). Monetary Policy Transmission Channels and Policy Instruments. Retrieved form http://people.ucsc.edu/ walshc/MyPapers/Walsh_ ChannelsandInstruments.pdf (20.01.2014).

Wojtyna, A. (2001). Skuteczność polityki pieniężnej w warunkach niskiej inflacji: problem zerowej granicy nominalnych stóp procentowych. Bank i Kredyt, 33(7).

Wright, J. H. (2012). What does Monetary Policy do to Long-term Interest Rates at the Zero Lower Bound?. Economic Journal, 122(564). DOI: http://dx.doi.org/ 10.1111/j.1468-0297.2012.02556.x.

Yates, T. (2002). Monetary Policy and the Zero Bound to Interest Rates. A Review. ECB Working Papers, 190. DOI: http://dx.doi.org/10.1111/j.09500804.2004.00227.x.

Żywiecka, H. (2013). Niestandardowe działania banków centralnych $w$ warunkach globalnego kryzysu finansowego. Warszawa: $\mathrm{CeDeWu}$. 